\title{
Pengaruh Ukuran perusahaan dan Ukuran Komite Audit terhadap Pengungkapan Corporate Social Responsibility
}

(Studi Empiris Pada Perusahaan Pertambangan yang Terdaftar Pada BEI Tahun 2014-2018)

\author{
Jaenal Abidin \\ Universitas Pamulang \\ Jaenalabidin328@gmail.com
}

\author{
Siska Anggun Lestari \\ Universitas Pamulang \\ anggunsiskasiska@gmail.com
}

\begin{abstract}
The purpose of this study was to determine the effect of company size on corporate social responsibility disclosure and to determine the effect of audit committee size on corporate social responsibility disclosure, and to determine the effect of company size and audit committee size together on corporate social responsibility disclosure in mining companies in the period 2014-2018. Data collection using secondary data obtained from the Indonesia Stock Exchange. The population in this study are mining companies listed on the Indonesia Stock Exchange. Sampling with puposive sampling method, there are 155 samples. The method of analysis uses multiple linear regression. The results of the study concluded that the size of the company and the size of the audit committee simultaneously had a significant effect on corporate social responsibility disclosure, company size had no significant effect on corporate social responsibility disclosure, and the size of the audit committee had a significant effect on corporate social responsibility disclosure.
\end{abstract}

\section{Keywords: Company Size, Audit Committee Size, Corporate Social Responsibility}

\section{PENDAHULUAN}

\subsection{Latar Belakang}

Terdapat tiga tanggung jawab perusahaan yang harus dilakukan secara bersama-sama dan seimbang terhadap pemegang kepentingan, yaitu tanggung jawab ekonomi, tanggung jawab atas hukum, dan tanggung jawab sosial. Pandangan dalam dunia usaha dimana perusahaan hanya bertujuan untuk mendapatkan keuntungan yang setinggitingginya tanpa memperhatikan dampak yang muncul dari kegiatan usahanya kini sudah tidak dapat diterima lagi. 
Perkembangan dunia usaha saat ini menuntut perusahaan untuk meningkatkan kepeduliannya terhadap lingkungan sosial. Diharapkan perusahaan tidak hanya mementingkan manajemen dan pemilik modal namun juga karyawan, konsumen, masyarakat, dan lingkungannya. Tanggung jawab perusahaan terhadap lingkungannya sering disebut dengan CSR (Corporate Sosial Responsibility). Di jaman modern ini Corporate Social Responsibility (CSR) telah menjadi fenomena global yang tidak terlepas dari tuntutan masyarakat agar perusahaan lebih peduli terhadap lingkungan karena aktivitas perusahaan akan berdampak langsung pada lingkungan mereka.

Terlepas dari kontroversi yang menyertainya, perusahaan terutama yang Berbasis sumber daya alam berkewajiban untuk melaksanakan CSR. Walaupun CSR seharusnya bersifat sukarela. Dalam UU PT tersebut definisi tanggung jawab sosial dan lingkungan lebih menitikberatkan kepada pengembangan komunitas (community development). Diluar kewajiban untuk mengikuti peraturan, CSR memang sepatutnya dilaksanakan oleh perusahaan, dengan kesadaran sendiri dan bersifat sukarela. Bibit CSR memang awalnya bersemi dari motif filantropik perusahaan yang acap bersifat spontanitas dan belum terkelola dengan baik. Selanjutnya dorongan eksternal berupa tuntutan masyarakat dan dorongan internal perusahaan agar lebih peduli dan bertanggungjawab terhadap lingkungannya. Di tengah masayarakat dunia yang semakin kritis dan peduli terhadap keberlangsungan lingkungan dalam jangka panjang dan menjunjung nilai-nilai etika, CSR menjadi keharusan bagi perusahaan. Apalagi perusahaan memperoleh manfaat dalam kegiatan CSR ini, yang terutama berkaitan dengan manajemen reputasi. CSR yang awalnya merupakan kegiatan filantropik ini pun berubah menjadi strategic philanthropy, yang dikaitkan dengan strategi perusahaan dan dikelola secara profesional.

Ada beberapa kasus perusahaan yang melakukan kegiatan produksi namun berdampak pada lingkungan. Seperti contoh kasus perusahaan pertambangan pada tahun 2006 yaitu banjir lumpur panas Lapindo di Kabupaten Sidoarjo, Jawa Timur. Semburan lumpur panas ini menyebabkan tergenangnya kawasan pemukiman, pertanian, dan perindustrian di tiga kecamatan sekitar PT Lapindo beroperasi. Selain itu pada tahun 2013, terowongan PT Freeport Indonesia di Big Gossan, Tembagapura, Papua mengalami runtuh sehingga memakan banyak korban yaitu mencapai 21 orang. Pada tahun 2014 PT Indo Tambangraya Megah, Tbk menghasilkan 29,1 juta ton batubara, perusahaan tersebut berusaha mengalihkan aliran sungai sehingga perusahaan bisa melakukan penambangan di Sungai Santan.Pengungkapan CSR umumnya dipengaruhi faktor-faktor terkait ukuran perusahaan, profitabilitas, leverage, kualitas audit, ukuran KAP, ukuran komite audit, kepemilikan institusional, kepemilikan publik, dewan komisaris dan ukuran direksi..

Penelitian yang dilakukan oleh Pradana (2017) menyatakan bahwa komite audit tidak berpengaruh terhadap pengungkapan CSR, namun ukuran perusahaan berpengaruh positif terhadap pengungkapan pertanggungjawaban sosial perusahaan. Sedangkan penelitian Erwanti dan Haryanto (2017) menunjukkan bahwa ukuran perusahaan dan ukuran komite audit tidak 
berpengaruh terhadap pengungkapan tanggungjawab sosial perusahaan. Berbanding dengan penelitian yang dilakukan oleh Krisna dan Novrys (2016) yang membuktikan bahwa ukuran perusahaan dan ukuran komite audit berpengaruh terhadap pengungkapan corporate social responsibility. Dijelaskan dalam Erwanti dan Haryanto (2017:2) ukuran perusahaan adalah salah satu variabel yang diduga mempengaruhi pengungkapan tanggung jawab sosial perusahaan. Bahwa perusahaan besar umumnya memiliki aktiva yang besar, penjualan besar, skill karyawan yang baik, sistem informasi canggih, jenis produk yang banyak, struktur kepemilikan lengkap, sehingga membutuhkan tingkat pengungkapan yang lebih besar. Perusahaan yang besar cenderung memiliki aktivitas yang lebih banyak dan kompleks, maka pelaksanaan CSR yang dilakukan oleh perusahaan dapat digunakan untuk menghindari resiko yang akan ditanggung di masa depan (Dewi dan Dita, 2018:57).

\subsection{Perumusan Masalah}

Berdasarkan latar belakang masalah di atas, dapat disusun permasalahan sebagai berikut:

1. Apakah ukuran perusahaan dan ukuran komite audit berpengaruh terhadap pengungkapan Corporate Social Responsibility (CSR) pada perusahaan sektor pertambangan yang terdaftar di BEI tahun 2014-2018?

2. Apakah ukuran perusahaan berpengaruh terhadap pengungkapan Corporate Social Responsibility (CSR) pada perusahaan sektor pertambangan yang terdaftar di BEI tahun 2014-2018?

3. Apakah ukuran komite audit berpengaruh terhadap pengungkapan Corporate Social Responsibility (CSR) pada perusahaan sektor pertambangan yang terdaftar di BEI tahun 2014-2018?

\subsection{Tujuan Penelitian}

Berdasarkan permasalahan yang telah diuraikan di atas, maka tujuan penelitian ini adalah:

1. Untuk mengetahui dan memberikan bukti empiris pengaruh ukuran perusahaan dan ukuran komite audit terhadap pengungkapan Corporate Social Responsibility (CSR) pada perusahaan sektor pertambangan yang terdaftar di BEI tahun 2014-2018.

2. Untuk mengetahui dan memberikan bukti empiris pengaruh ukuran perusahaan terhadap pengungkapan Corporate Social Responsibility (CSR) pada perusahaan sektor pertambangan yang terdaftar di BEI tahun 2014-2018.

3. Untuk mengetahui dan memberikan bukti empiris pengaruh ukuran komite audit terhadap pengungkapan Corporate Social Responsibility (CSR) pada perusahaan sektor pertambangan yang terdaftar di BEI tahun 2014-2018.

\section{TINJAUAN PUSTAKA}

\subsection{Legitimacy Theory}

Gray dkk. dalam Manjalang (2016 : 11) berpendapat bahwa legitimasi merupakan sistem pengelolaan perusahaan yang berorientasi pada keberpihakan terhadap masyarakat, pemerintah, individu dan kelompok masyarakat. Untuk itu, sebagai suatu sistem yang mengedepankan keberpihakan kepada masyarakat, operasi perusahaan harus sejalan dengan harapan masyarakat. Hal ini dapat dijadikan sebagai wahana untuk mengonstruksi strategi perusahaan, terutama dalam upaya memposisikan diri di tengah lingkungan masyarakat serta menjalin hubungan baik 
dengan lingkungan masyarakat di sekitar perusahaan.

\subsection{Pengungkapan Corporate Social Responsibility}

Pengungkapan CSR merupakan sebuah konsep tentang perlunya sebuah perusahaan membangun hubungan harmosnis dengan masyarakat dan stakeholder lainnya. CSR saat ini menjadi elemen penting dari dialog antara perusahaan dan stakeholders mereka dan terus menuai perhatian atas agenda korporasi. Magnan dan Ferrel dalam Susanto (2007:21) mengemukakan CSR sebagai "A business acts in socially responsible manner when its decision and account for and balance diverse stake holder interest". Pengukuran dilakukan dengan melihat pengungkapan tanggung jawab sosial perusahaan mencakup dalam tujuh kategori antara lain: lingkungan, energi, kesehatan dan keselamatan tenaga kerja, lain-lain tenaga kerja, produk, keterlibatan masyarakat, dan umum. Ketujuh kategori tersebut terbagi dalam 90 item pengungkapan. Berdasarkan peraturan Bapepam No VIII G.2 tentang laporan tahunan dan kesesuaian item untuk diaplikasikan di Indonesia maka dilakukan penyesuaian hingga tersisa 78 item pengungkapan (Anggraini, 2018:47). Untuk menghitung CSRI menurut Kristiana, dkk (2016 : 154 ) adalah sebagai berikut :

$$
\operatorname{CSRli} \frac{\sum X_{y i}}{n i}
$$

Dimana :

$$
\begin{aligned}
\text { CSRIi }= & \text { Corporate Social Responsibility } \\
& \text { Index pada perusahaan } \mathrm{i} \\
\Sigma \mathrm{Xyi}= & \begin{array}{l}
\text { Jumlah nilai yang diungkapkan } \\
\text { dalam annual report }
\end{array}
\end{aligned}
$$

ni $=$ Total keseluruhan item (78) Dengan demikian, $0 \leq \mathrm{CSRIj} \leq 1$.

\subsection{Ukuran Perusahaan}

Ukuran perusahaan menunjukkan adanya perbedaan resiko usaha perusahaan besar dan kecil. Ukuran perusahaan menggambarkan besar kecilnya suatu perusahaan yang dapat ditunjukkan dengan total aktiva, total penjualan, ratarata tingkat penjualan, dan rata-rata total aktiva. Semakin besar ukuran perusahaan maka semakin baik teknologi dan sistem dalam perusahaan serta adanya kemudahan bagi manajemen dalam menggunakan aktiva perusahaan akan mendorong peningkatan kinerja perusahaan. Berdasarkan referensi penelitian terdahulu maka ukuran perusahaan merupakan besar kecilnya perusahaan yang diukur dari total aset neraca pada akhir tahun. Rumus

Size $=$ Log (Total Aktiva) uran perusahaan (2018:63) adalah

\subsection{Ukuran Komite Audit}

Ukuran komite audit merupakan jumlah anggota komite audit dalam suatu perusahaan. Skala nominal menurut Ghozali (2018:3) merupakan skala pengukuran yang menyatakan kategori, atau kelompok dari suatu subyek. Skala pengukuran untuk variabel ini adalah skala nominal yaitu dengan menghitung jumlah anggota komite audit dalam laporan tahunan perusahaan yang tercantum pada laporan tata kelola perusahaan (Erwanti dan Haryanto, 2017:5).

Ukuran Komite Audit $=\sum$ Komite audit 


\section{METODE PENELITIAN}

\subsection{Jenis Penelitian}

Jenis dan sumber data jenis yang digunakan dalam penelitian ini adalah data sekunder, sumber data yang diperoleh melalui dokumen-dokumen perusahaan dan laporan-laporan perusahaan lainnya. Data diperoleh dari laporan keuangan perusahaan pertambangan yang terdaftar di Bursa Efek Indonesia (BEI) periode 2014-2018.

\section{HASIL PENELITIAN DAN PEMBAHASAN}

Metode analisis pendekatan ini menggunakan pendekatan dengan metode kuantitatif. Jenis penelitian ini adalah menggunakan deskriptif. Dalam penelitian ini metode analisis data yang digunakan adalah metode analisis statistik dengan menggunakan software SPSS 24. Untuk pengujian hipotesis dilakukan analisis regresi linear berganda model regresi yang digunakan adalah sebagai berikut :

linier sederhana dapat dicari dengan rumus :

$Y=\alpha+\beta x 1+\beta x 2+e$

Dimana :

$\mathrm{Y}=$ Pengukapan CSR

$\alpha=$ Konstanta

$\beta=$ Koefisien Regresi (Beta)

$\mathrm{X}_{1}=$ Ukuran Perusahaan

$\mathrm{X}_{2}=$ Ukuran Komite Audit

$\mathrm{E}=$ Standar Error

Pengujian asumsi klasik yang dilakukan terdiri atas uji normalitas, uji multikolinearitas, uji heterokedastisitas xn uji utokorelasi. Hasil pengujian asumsi klasik ini menggunkan software SPSS 24.

\subsection{Hasil Analisis}

1. Uji Normalitas
Ada dua cara untuk mendeteksi uji normalitas dengan analisis statistik dan analisi grafik.

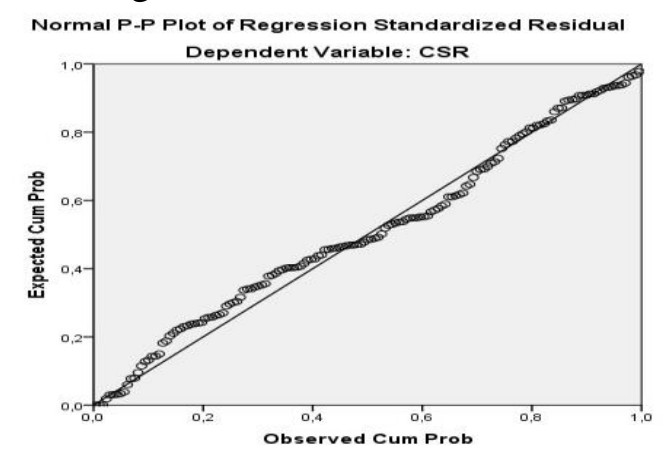

Sumber: Hasil olah data SPSS 24

Untuk dapat dilihat bahwa data atau titik-titik menyebar disekitar garis diagonal, sehingga dapat disimpulkan bahwa data yang diolah tidak menyalahi asumsi normalitas. Maka dapat disimpulkan bahwa model regresi pada penelitian ini memenuhi syarat untuk menjadi model regresi yang baik karena merupakan model regresi yang memiliki distribusi normal atau mendekati normal, yang artinya uji normalitas terpenuhi.

\section{Multikolineritas}

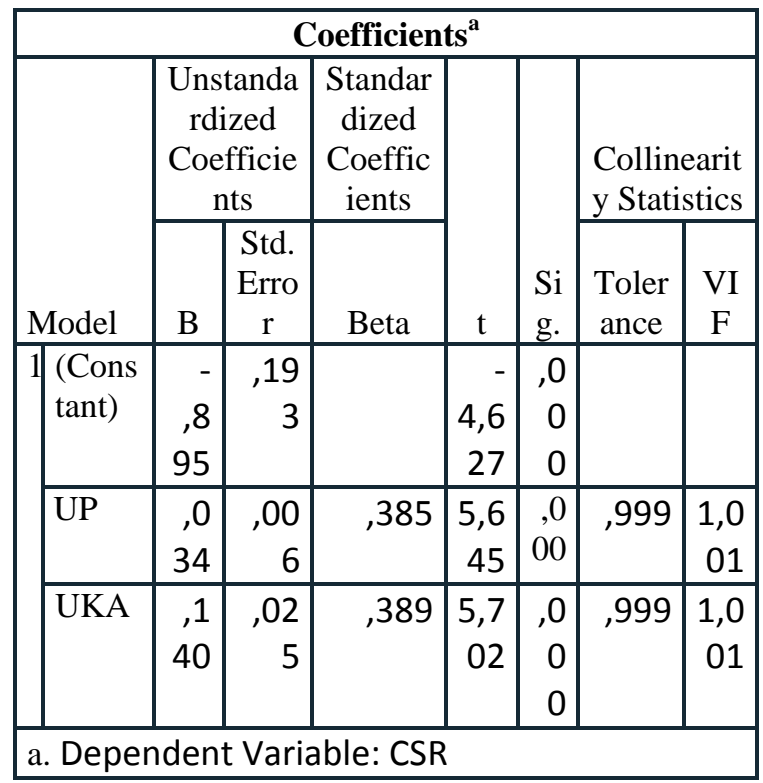


Sumber: Hasil olah data SPSS 24.

Berdasarkan tabel di atas, dapat dilihat bahwa angka pada kolom nilai VIF diperoleh angka sebesar 1,001 dimana nilai $1,001<10$ dan nilai tolerance 0,999 dimana nilai $0,999>$ 0,10 . Sehingga dapat disimpulkan bahwa data yang digunakan terbebas dari multikolinearitas atau tidak terjadi korelasi antar variabel independen.

\section{Heteroskedastisitas}

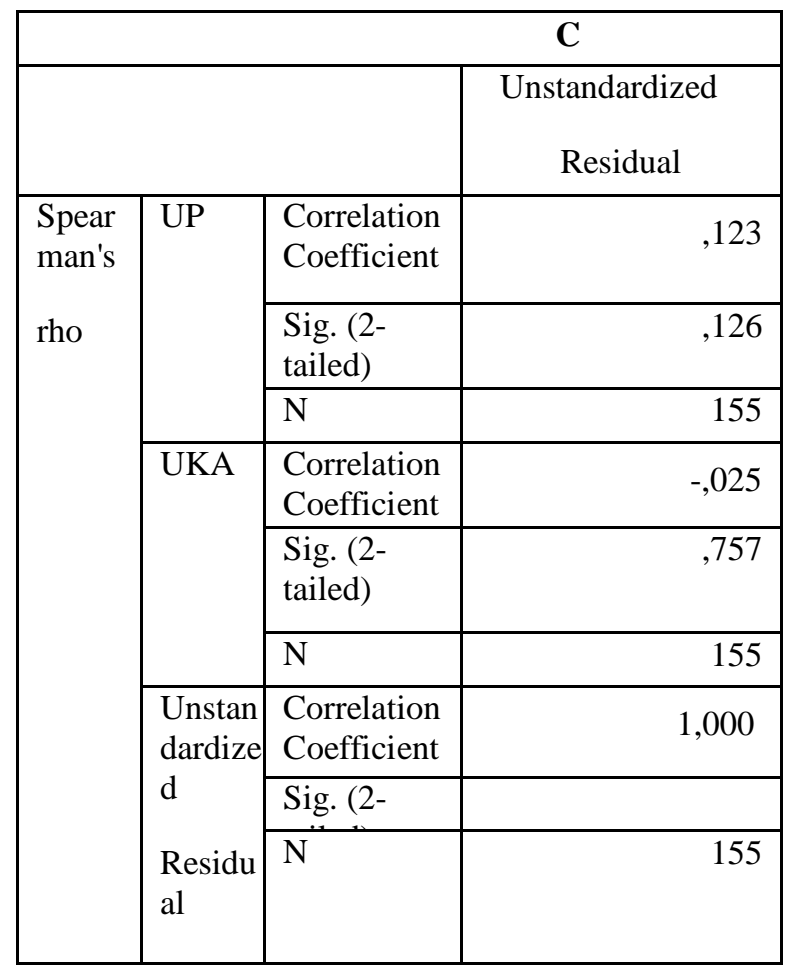

Sumber: Hasil olah data SPSS 24.

Berdasarkan hasil uji heteroskedastisitas dengan spearman's rho diatas, variabel independen ukuran perusahaan memperoleh nilai sig (2-tailed) sebesar 0,126 dan ukuran komite audit nilai sig (2tailed) sebesar 0,757. Dimana kedua variabel independen tersebut mempunyai nilai sig (2-tailed) $>0,05$, maka dapat disimpulkan bahwa tidak terjadi masalah heteroskedastisitas pada model regresi.

\section{Autokorelasi}

\begin{tabular}{|c|c|c|c|c|c|}
\hline & & Mode & Summa & & \\
\hline $\begin{array}{l}\text { Mod } \\
\text { el }\end{array}$ & $\mathrm{R}$ & $\begin{array}{c}\mathrm{R} \\
\text { Squar } \\
\mathrm{e}\end{array}$ & $\begin{array}{c}\text { Adjuste } \\
\text { d R } \\
\text { Square }\end{array}$ & $\begin{array}{c}\text { Std. } \\
\text { Error } \\
\text { of the } \\
\text { Estimat } \\
\text { e }\end{array}$ & $\begin{array}{c}\text { Durbi } \\
\text { n- } \\
\text { Watso } \\
\text { n }\end{array}$ \\
\hline 1 & $\begin{array}{r}541 \\
\mathrm{a}\end{array}$ & ,292 & ,783 & $\begin{array}{r}, 12299 \\
3\end{array}$ & ,440 \\
\hline a. $\operatorname{Pr}$ & ors: & nstan & UKA & & \\
\hline b. De & lent & riable & CSR & & \\
\hline
\end{tabular}

Berdasarkan hasil pengujian di atas diperoleh hasil DW sebesar 0,440 dimana nilai $-2<0,440<+2$ sehingga dapat disimpulkan bahwa data yang digunakan tidak terjadi masalah autokorelasi.

\section{Uji Koefisien Determinasi}

\begin{tabular}{|c|c|c|c|c|c|}
\hline \multicolumn{6}{|c|}{ Model Summary $^{b}$} \\
\hline $\begin{array}{l}\text { Mod } \\
\text { el }\end{array}$ & $\mathrm{R}$ & $\begin{array}{c}\mathrm{R} \\
\text { Squar } \\
\mathrm{e}\end{array}$ & $\begin{array}{c}\text { Adjuste } \\
\text { d R } \\
\text { Square }\end{array}$ & $\begin{array}{c}\text { Std. } \\
\text { Error } \\
\text { of the } \\
\text { Estimat } \\
\mathrm{e}\end{array}$ & $\begin{array}{c}\text { Durbi } \\
\text { n- } \\
\text { Watso } \\
\text { n }\end{array}$ \\
\hline 1 & $\begin{array}{r}541 \\
\mathrm{a}\end{array}$ & ,292 & ,783 & $\begin{array}{r}12299 \\
3\end{array}$ & ,440 \\
\hline \multicolumn{6}{|c|}{ a. Predictors: (Constant), UKA, UP } \\
\hline \multicolumn{6}{|c|}{ b. Dependent Variable: CSR } \\
\hline
\end{tabular}

Sumber: Hasil olah data SPSS 24

Berdasarkan tabel di atas dapat dilihat bahwa nilai koefisien adjusted $R^{2}$ yang dihasilkan oleh variabel-variabel independen sebesar 0,283 yang artinya $28,3 \%$ variabel pengungkapan corporate social responsibility dijelaskan oleh variabel ukuran perusahaan dan ukuran komite audit. Sehingga hasil ini memberikan penegasan bahwa pembahasan terkait corporate social responsibility memang tidak terlepas dari ukuran 
perusahaan dan ukuran komite audit. Sedangkan sisanya $71,7 \%$ dijelaskan oleh variabel lain diluar variabel yang digunakan dalam penelitian ini.

\section{Uji t (Parsial)}

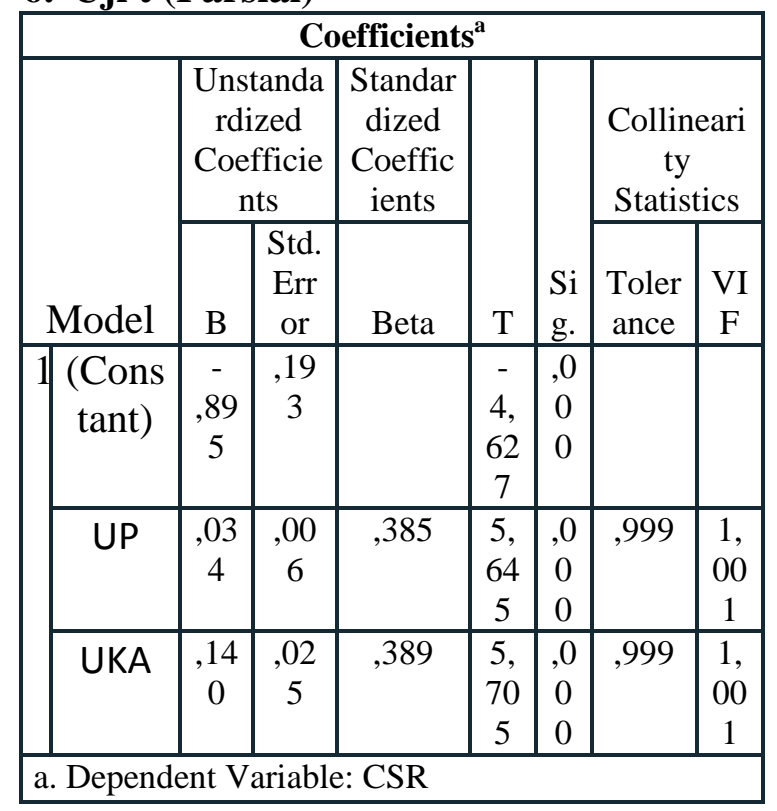

Sumber: Hasil olah data SPSS 24

Berdasarkan tabel di atas untuk ukuran perusahaan memperoleh angka signifikan 0,000 dimana nilai signifikan lebih kecil daripada nilai standar signifikan atau 0,000 $<0,05$ maka $\mathrm{H}_{1}$ diterima variabel. Untuk

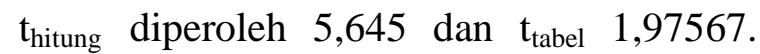
Hasil uji t dikatakan berpengaruh jika $t_{\text {hitung }}$ $>\mathrm{t}_{\text {tabel}}$, karena 5,645>1,97567 maka dapat disimpulkan bahwa ukuran perusahaan berpengaruh secara signifikan terhadap pengungkapan corporate social responsibility, sehingga $\mathrm{H}_{2}$ diterima. Ukuran komite audit memperoleh angka signifikan sebesar 0,000 dimana nilai signifikan lebih kecil dari nilai signifikan standar atau $0,000<0,05$ maka $\mathrm{H}_{3}$ diterima variabel. Untuk $t_{\text {hitung }}$ diperoleh sebesar 5,705 dan $\mathrm{t}_{\text {tabel }}$ 1,97567. Dimana nilai 5,705 > 1,97567 maka dapat disimpulkan bahwa ukuran komite audit berpengaruh secara positif signifikan terhadap pengungkapan corporate social responsibility sehingga $\mathrm{H}_{3}$ diterima.

\section{Uji F (Simultan)}

\begin{tabular}{|c|c|c|c|c|c|c|}
\hline \multicolumn{7}{|c|}{ ANOVA $^{a}$} \\
\hline \multicolumn{2}{|c|}{ Model } & $\begin{array}{c}\text { Sum of } \\
\text { Square } \\
\text { s }\end{array}$ & df & $\begin{array}{l}\text { Mean } \\
\text { Squar } \\
\mathrm{e}\end{array}$ & $\mathrm{F}$ & Sig. \\
\hline 1 & $\begin{array}{l}\text { Regressio } \\
\mathrm{n}\end{array}$ & ,950 & 2 & 475 & $\begin{array}{r}31,41 \\
6 \\
\end{array}$ & $\begin{array}{r}, 000 \\
\mathrm{~b}\end{array}$ \\
\hline & Residual & 2,299 & $\begin{array}{r}15 \\
2\end{array}$ &, 015 & & \\
\hline & Total & 3,250 & $\begin{array}{r}15 \\
4\end{array}$ & & & \\
\hline \multicolumn{7}{|c|}{ a. Dependent Variable: CSR } \\
\hline \multicolumn{7}{|c|}{ b. Predictors: (Constant), UKA, UP } \\
\hline
\end{tabular}

Sumber: Hasil olah data SPSS 24

Berdasarkan tabel Anova tersebut diperoleh $F_{\text {hitung }}$ sebesar 31,416 dengan signifikansi 0,000 dan $F_{\text {tabel }}$ sebesar 3,06. Dimana 31,416 > 3,06 dan 0,000 < 0,05 maka $\mathrm{H}_{1}$ diterima. Berdasarkan dari hasil pengujian maka dapat disimpulkan bahwa variabel independen ukuran perusahaan dan ukuran komite audit secara simultan berpengaruh terhadap pengungkapan corporate social responsibility.

\section{Penutup}

\subsection{Kesimpulan}

Penelitian ini bertujuan untuk mengetahui apakah ukuran perusahaan dan ukuran komite audit berpengaruh terhadap pengungkapan corporate social responsibility pada perusahaan sektor pertambangan yang terdaftar di BEI periode 2014 -2018. Dimana perusahaan yang memenuhi kriteria yang telah ditentukan sebelumnya sebanyak 31 perusahaan sehingga sampel dalam penelitian ini adalah sebanyak 155 laporan keuangan. Penelitian ini dilihat berdasarkan hasil analisis data, pengujian hipotesis dan pembahasan dari uraian bab-bab sebelumnya. 
Sehingga berdasarkan hasil penelitian dan pembahasan, maka dapat ditarik kesimpulan sebagai berikut:

1. Secara simultan ukuran perusahaan dan ukuran komite audit berpengaruh signifikan terhadap pengung kapan corporate social responsibility.

2. Ukuran perusahaan berpengaruh signifikan terhadap pengungkapan corporate social responsibility

3. Ukuran komite audit berpengaruh signifikan terhadap pengungkapan corporate social responsibility

\subsection{Saran}

Berdasarkan hasil pembahasan penelitian dan kesimpulan diatas maka dapat diberikan saran-saran bagi peneliti selanjutnya untuk dapat memperbaiki halhal berikut ini:

1. Variabel yang digunakan dalam penelitian ini hanya dua variabel, oleh sebab itu pada penelitian selanjutnya dapat menambahkan variabel lainnya yang berhubungan dengan pengungkapan corporate social responsibility. Sehingga dapat memberikan gambaran yang lebih luas mengenai faktor apa saja yang mempengaruhi pengungkapan corporate social responsibility selain ukuran perusahaan dan ukuran komite audit.

2. Menambah periode penlitian, dengan periode yang lebih panjang diharapkan hasil yang diperoleh dapat lebih akurat

3. Memperluas sampel penelitian dengan klasifikasi perusahaan selain sektor pertambangan.

4. Bagi perusahaan, hendaknya untuk tetap mengungkapkan laporan pengungkapan corporate social responsibility tanpa melihat seberapa besar ukuran perusahaan dan ada tidaknya komite audit

\section{DAFTAR PUSTAKA}

Anggraini, Novia Dwi., (2018). "Pengaruh Profitabilitas, Leverage dan Komite Audit Terhadap Pengungkapan Corporate Social Responsibility Pada Perusahaan Manufaktur yang Terdaftar di BEI". Skripsi. Tangerang Selatan. Fakultas Ekonomi. Universitas Pamulang.

Bramatalla, Erlian Fitrah., (2016). "Pengaruh Corporate Governance dan Profitabilitas Terhadap Luas Pengungkapan Corporate Social Resposibility". Skripsi. Bandar Lampung. Universitas Lampung

Dermawan, Decky., dan Tita Deitiana., (2014). "Faktor-Faktor yang Mempengaruhi Pengungkapan Corporate Social Responsibility". Jurnal Bisnis dan Akuntansi. Jakarta. STIE Trisakti.

Dewi dan Dita Nur Khafi., (2018). "Faktor-faktor Yang Mempengaruhi Pengungkapan Corporate Social Responsibility". Jurnal Ilmiah Akuntansi dan Ekonomi Volume 1 No. 3 Februari 2018. Fakultas Ekonomi Program Studi Akuntansi. Universitas Satya Negara Indonesia

Erwanti, Yulinia., dan Haryanto., (2017). "Pengaruh Ukuran Perusahaan, Profitabilitas, Dewan Komisaris, Komite Audit dan Kualitas Audit Terhadap Pengungkapan Informasi Pertanggungjawaban Sosial". Jurnal Volume 6 Nomor 4, Halaman 1-14. 
Fakultas Ekonomi dan Bisnis. Universitas Diponegoro

Fatimah, dkk. (2015). "Pengaruh Komisaris Independen dan Komite Audit Terhadap Pengungkapan Corporate Social Responsibility Perusahaan Pertambangan di Bursa Efek Indonesia Periode 2012-2014”. Jurnal. Riau.Fakultas Keguruan dan Ilmu Pendidikan. Universitas Riau.

Ghozali, Imam., "Aplikasi Analisis Multivariate Dengan Program IBM SPSS 25 Edisi 9". Semarang: Universitas Diponegoro. 2018.

Gujarati, Damodar N., "Dasar-Dasar Ekonometrika Edisi 5 Buku 1". Jakarta: Salemba Empat. 2014.

Harahap, Sofyan Syafri., "Teori Akuntansi Edisi Revisi 2011". Jakarta: Rajawali Pers. 2011

Kieso, dkk., "Akuntansi Intermediate Edisi Kedua Belas Jilid 1". Jakarta: Erlangga. 2008

Klau, Cunegundis Blandina., (2017). "Faktor-Faktor yang Mempengaruhi Pengungkapan Corporate Social Responsibility”. Skripsi. Surabaya. Fakultas Bisnis. Universitas Katolik Widya Mandala.

Krisna, Aditya Dharmawan., dan Suhardianto Novrys., (2016). "Faktor-Faktor Yang Mempengaruhi Pengungkapan Tangung Jawab Sosial". Jurnal akuntansi dan keuangan Vol 18. No.

2. Hal 119-128. Surabaya.

Kristiana, dkk., (2016). "Analisis FaktorFaktor Yang Mempengaruhi Pengungkapan CSR Pada Perusahaan Manufaktur Sektor Industri Barang Konsumsi”. Jurnal Akuntansi dan Sistem Teknologi
Informasi Vol $12 \mathrm{Hlm}$ 150-1158. Surakarta. Universitas Slamet Riyadi

Manjalang, Reza., (2016). "Pengaruh Good Corporate Governance Dan Kepemilikan Saham Publik Terhadap Tingkat Pengungkapan Corporate Social Responsibility". Skripsi. Yogyakarta. Fakultas Ekonomi. Universitas Negeri Yogyakarta.

Muliawan, Pratama Nandra., (2014). "Faktor-Faktor yang Mempengaruhi pengungkapan CSR Pada Perusahaan Yang Terdaftar Pada Bursa Efek Indonesia Tahun 2012”. Skripsi. Semarang. Fakultas Ekonomi dan Bisnis. Universitas Katolik Soegijapranata.

Pradana, Andre Virgia., (2017). "Pengaruh Good Corporate Governance, Profitabilitas, dan Ukuran Perusahaan Terhadap Pengungkapan Corporate Social Responsibility". Skripsi. Surakarta. Fakultas Ekonomi dan Bisnis. Universitas Muhammadiyah Surakarta.

Sha, Thio Lie., (2014). "Pengaruh Ukuran Perusahaan, Ukuran Dewan Komisaris, Profitabilitas, dan Leverage Terhadap pengungkapan Tanggungjawab Perusahaan Manufaktur yang Terdaftar di BEI 2009-2011". Jurnal Akuntansi Volume XVIII No. O1. Jakarta. Universitas Tarumanegara.

Sudjana, Ni Luh., dan Sudana I Putu., (2017). "Faktor-Faktor Yang Mempengaruhi Pengungkapan CSR Dengan Profile Perusahaan Sebagai Variabel Pemoderasi", dalam E- 
jurnal Akuntansi Universitas Udayana Vol. 10.3. hal 2468-2492. Denpasar. Universitas Udayana.

Sugiyono. "Metode Penelitian Kuantitatif, Kualitatif dan R\&D". Bandung: Alfabeta. 2017

Sumardi, dkk., "Akuntansi 1A Siklus Akuntansi Perusahaan Jasa". Jakarta: Yudhistira. 2006.

Sunyoto, Danang., "Metodologi Penelitian Akuntansi”. Yogyakarta: Refika Aditama. 2016.
Susanto. "A Strategic Management Approach Corporate Social Responsibility". Jakarta: The Jakarta Consulting Group. 2007

Wati, Lela Nurlaela., (2016). "FaktorFaktor yang Mempengaruhi Pengungkapan Corporate Social Responsibility Dengan GRI 3". Jurnal Ecodemica Vol. 2 No. 2. Jakarta. STIE Muhammadiyah Jakarta. 